\title{
PEMAHAMAN UMAT KATOLIK MADIUN TERHADAP KONSTITUSI GAUDIUM ET SPES DALAM KEHIDUPAN POLITIK PRAKTIS
}

\author{
Kasimirus, Agustinus Wisnu Dewantara* \\ STKIP Widya Yuwana \\ kasimirus90@gmail.com \\ ${ }^{*}$ penulis korespondensi, dewantaracm@gmail.com
}

\begin{abstract}
Apolitical praxis has been grown widely. Being a qualified Catholic politicianis a fundamental matter because it serves as a mediator between Church and state. A Catholic politician comprehensive under standing's GS is one of parameters for a qualification to involve in social and political practices. The research was designed to answer some fundamental guestions as the following: How far the Catholics in Madiun understand about the document of GS on political praxis? This research conducted by using a qualitative method. The results of researchs howed that $100 \%$ respondents were knowing about GS, although some of them did not deeply knowing. Respondents then disclosed that the contents of GS was related to both divine and human vocation to participate and being responsible in social and political life for human well-being (62,5\%). According to respondents, bonum commune was main goal of the Catholic Church's involvement in social and political praxices (75\%). The result all of research showed that the formation for social and political addres can be started from the familly pastoral ministry, and to introduce such Christian social and political values for Catholic faithful started from the early ages.
\end{abstract}

Keywords: Gaudiumet Spes, Politics Praxis, Catholics.

\section{PENDAHULUAN}

Persoalan hidup bermasyarakat semakin kompleks dan memprihatinkan. Pertarungan politik pada pesta demokrasi (pemilu serentak) 2019 berlangsung sengit. Politik mengeliminasi kaum lemah dan korupsi semakin marak terjadi. Orang Katolik di parlemen dan pusat pemerintahan kurang memberi dampak yang signifikan sebagai garam dan terang dunia untuk skala luas yakni untuk kesejahteraan umum. Hakekat manusia sebagai makhluk politik (zoon politicon) semakin sulit untuk dihidupi. Singkatnya, praktek politik saat ini berjalan tanpa moral karena dipengaruhi oleh kepentingan-kepentingan material, ideal, cara berpikir kelas sosial menengah ke atas. Apolitik mengakibatkan terbentuknya politik yang mahal, diskriminatif, pragmatis, sehingga ruang politik praktis hanya diisi oleh kelompok konglomerat (borjuis nasional), para teknokrat yang 
bermentalitas pragmatis dan saling mengisi kepentingan (INFID, terj., Anik, dkk. 1999: 36). Impian mensejahterakan rakyat lebih sering tampil di publik sebagai slogan saja.Hal tersebutmenjadi keprihatinan mendalam tentang hidup bersosialpolitik saat ini dan yang akan datang.

Survei yang dilakukan LSI bersama SMRC, sebagaimana dikutip Adinugroho (Buletin Psikologi. 24.2.2016: 80), menunjukkan bahwa eksistensi partai politik di Indonesia menjadi institusi yang dipandang negatif oleh rakyat.Sikap apatis terhadap politik mewabah juga dalam Gereja Katolik di Indonesia, meskipun umat Katolik tidak pernah absen dalam sepak terjang politik di Indonesia (Wuarmanuk, HIDUP, 17/02/2019: 8-9). Ada tiga asumsi adanya sikap apatis umat Katolik terhadap politik praktis, yakni:umat tidak memahami ajaran sosial khususnya Gaudium et Spes, yang selanjutnya disebut GS; umat Katolik merasa perlu menghindari politik untuk menghindari dosa, sebab politik dipandang lahan subur praktik amoral (Olla, 2014: 2); dan umat Katolik cenderung mencari aman (Anicetus, 2004: 7). Umat Katolik yang terlibat dalam politik praktis tetapi tidak memahami spiritualitas politik Kristiani akan berpolitik tanpa moral, sehingga keterlibatan sosial-politik tidak berbekas bagi bonum commune.

Gereja sebagai umat Allah yang berziarah perlu menyadari bahwa hampir seluruh gerak kehidupan bermasyarakat dunia, termasuk kehidupan Gereja ditentukan oleh hukum-hukum positif yang dibuat oleh negara. Hukum atau aturan dibuat, ditetapkan, dipromulgasikan sebagai hukum adil oleh legislator. Bahayanya, jika hukum positif dibuat oleh legislator atau elit politik yang kotor, yang mencari kekuasaan tanpa moral, maka maka hukum yang dilahirkan dan harus ditaati rakyat merupakan produk nurani serakah yang akan merusak hidup bersama.

Gereja tidak berpolitik secara praktis, namun Gereja berdosa bila acuh-tak acuh dan menutup diri terhadap tindak ketidakadilan, terhadap persoalan masyarakat, dan hukum irasional. Praktek politik yang memprihatinkan, apatisme umat Katolik, di satu sisi, panggilan Gereja yang sangat urgen dan tidak terelakkan dalam dunia politik praktis di sisi lain, mendesak peneliti menulis karya ilmiah ini. Penelitian ini menjawab pertanyaan pokok: apa itu Konstitusi GS, apa wacana GS tentang politik praktis, dan sejauh mana umat Katolik Madiun memahami ajaran GS tentang politik praktis? Penelitian dilaksanakan di wilayah Madiun, teritorial paroki St. Cornelius dan Mater Dei.

\section{PEMBAHASAN}

Konstitusi GS membuka pandangan umat Allah tentang tujuan kehadiran Gereja dalam konteks sosial-politik tertentu, seperti yang tersirat dalam penyataan berikut: 
"Kegembiraan dan harapan, duka dan kecemasan orang-orang zaman sekarang, terutama kaum miskin dan siapa saja yang menderita merupakan kegembiraan dan harapan, duka dan kecemasan para murid Kristus juga” (GS. 1).

\subsection{Arti Politik}

Masyarakat pada umumnya (common sense) memahami politik sebagai cara untuk merebut dan mempertahankan kekuasaan. Pandangan masyarakat umum tentang politik jauh dari makna hakiki politik, namun tidak dapat disalahkan, sebab kontestasi yang terjadi di ruang publik tidak lain adalah merebut dan mempertahankan kekuasaan demi kepentingan pribadi atau golongan tertentu.

Pengertian politik dapat ditinjau dari beberapa sisi (KBBI., 2008: 1091). Politik merupakan kata benda yang menunjuk katatanegaraan; kata "politik" merupakan kata kerja yang berarti tindakan (kebijakan, siasat); dan kata politik juga berarti prosedur, yaitu langkah-langkah atau cara-cara bertindak, kebijakankebijakan untuk menghadapi atau mengatasi persoalan hidup bersama dalam suatu polis. Wogaman (2000: 12-13) menegaskan:

"Politics is the polis or civil community, ordering its life together on the basic of the public good. And to be human is to be a participant in that kind to emphasize the struggle over power, that is largely as truggle over in other kinds of groups as in church politics, or corporate politics, or union politics, or school politics."

Secara etimologis, kata "politik" berasal dari Yunani “politeia”. Kata "politeia” berasal dari kata benda "polis" yang berarti kota atau negara, sedangkan warga negara disebut politicon (Bagus, 2003: 857). Singkatnya, politik adalah perihal ketatanegaraan, seni hidup bersama dalam masyarakat di suatu polis. Politik praktis dimengerti dari hubungannya dengan kepemerintahan, perkara mengelolah, mengarahkan, menyelenggarakan kebijaksanaan umum dan keputusan-keputusan atau kebijaksanaan yang menyangkut partai-partai yang berperan dalam kehidupan bernegara. Politik praktis mengambil pengertian politik sebagai suatu kata "prosedural”, yakni bermacam-macam kegiatan dalam suatu sistem negara, menyangkut proses menentukan tujuan-tujuan dari sistem negara, dan melaksanakan tujuan-tujuan bersama.

\subsection{Sekilas Politik dari Tinjauan Filsafat}

Politik tidak bisa dibicarakan tanpa moral, oleh karena itu tinjauan filsafat politik pada penelitian ini dilihat dalam diskursus moralitas politik. Istilah politik pertama kali dikemukakan oleh Aristoteles dalam sebuah risalah yang diberi judul politeia. Jauh sebelumnya, gagasan politik sudah ada dalam pemikiran Sokrates (469-399) yang beriktiar membangun manusia sempurna dan susila untuk 
mendukung tercapainya kesejahteraan negara, dimana keadilan dipandang sebagai turunan dari kebijaksanaan untuk mengatur kehidupan bersama (Sudiarja, dkk., 2006: 1035-1141). Aristoteles, dalam Riyanto (2011:15) mengatakan, politik merupakan cetusan aktivitas agung dari manusia sebagai makhluk sosial, rasional, dan makhluk moral. Aristoteles memasukkan politik sebagai cabang pengetahuan praktis, bagian dari etika yang berkaitan dengan manusia dalam hidup bersama. Maksud dan tujuan akhir politik dalam polis sama dengan maksud dan tujuan moral yaitu kebahagiaan vital setiap individu yang disebut eudaimonia (Lorens, 2002: 857).

Cakupan filsafat atau moralitas politik sangat luas, memiliki aspek-aspek dasariah yang tidak bisa diabaikan satu dengan yang lain. Berikut akan dijelaskan aspek-aspek yang membantu pemahaman mengenai hakekat politik. Pertama, aspek architectonic, yang menunjukkan politik adalah seni, kecakapan, kepandaian, keterampilan dan kebijaksanaan menangani hal praktis yang mengandaikan keanekaragaman teknik (tekné: kecakapan) (Riyanto, 2017: 37). Aristoteles, dalam Riyanto (2011: 37) mengatakan, pengelolahan pemerintah oleh politikus mengandaikan kapasitas kemampuan yang mencakup seluruh kecakapan teknik hidup sehari-hari, artinya politikus harus mengerti tentang etika, ilmu sosial, kebijakan publik, nilai-nilai budaya, filsafat dan filsafat bangsa.

Kedua, aspek refleksi, yaitu usaha pencarian kedalaman dan kebenaran dari keluhuran martabat manusia dan seluruh alam ciptaan. "Manusia hadir tidak hanya untuk mendengarkan, mengikuti perintah atau menjalankan hukum dan kewajiban. Manusia hadir untuk menggapai kedalaman dan kebenaran” (Riyanto, 2011: 40). Voegelin, dalam Riyanto (2011: 40) mengatakan, kesadaran ada dalam ranah order, keteraturan tata hidup dan kebersamaan. Refleksi manusia harus mencapai nilai, sebab politik adalah nilai dan nilai adalah politik itu sendiri. Nilainilai yang terintegrasi di dalam kontestasi politik dalam konteks Indonesia adalah nilai-nilai luhur bangsa yakni Pancasila (HIDUP, 17/02/2019).

Ketiga, aspek utilitarianisme, yaitu tindakan dinilai benar atau salah hanya demi akibat-akibatnya. Tindakan bernilai baik bila akibat tindakan menguntungkan, sebaliknya tindakan bernilai buruk bila akibat tindakan itu tidak menguntungkan (Rachels, 2004: 192-199). Skala untuk mengukur akibat tindakan adalah jumlah kebahagiaan (kegunaan) atau ketidakbahagiaan yang dihasilkan dari tindakan. Prinsip utilitarianisme adalah mengusahakan kebahagiaan banyak orang, dan dengan demikian akan menghanguskan orang yang kecil dan lemah. Praksis kebijakan tindakan utilitarian tampil dalam diskriminasi terhadap minoritas (Riyanto, 2011: 56).

Keempat, aspek bahasa yaitu alat propaganda. Pierre Bourdieu, dalam Riyanto (2011:64) mengatakan, "dalam dunia politik, bahasa bisa menjadi alat propaganda, artinya bahasa tidak sekadar menjelaskan kebenaran atau 
pengetahuan namun juga alat kekuasaan. "Bahasa mengungkapkan kehendak untuk berkuasa dengan kekuatan the art persuasion (Hardiman, 2004: 272-273). Tujuan persuasi dalam utilitarianisme bukan untuk meraih kebenaran melainkan kemenangan. Kekuasaan politik seringkali dimenangkan karena kata-kata bukan karena kebenaran. Politik diharapkan menggunakan bahasa untuk mengungkapkan kebenaran, mengusahakan keadilan dan kesejahteraan umum.

Kelima, aspek violatif, yang menunjukkan bahwa politik rentan terhadap kekerasan. Riyanto (2011: 72) mengatakan, aspek violatif dalam politik tampak pada politik yang rentan kekerasan, manipulasi, intrik-intrik, strategi kotor, ketidakadilan sistematis, kerancuan dan kekacuan. Aspek violasi politik dibonceng oleh pretensi manusia untuk menguasai. Noumann, dalam Wogaman (2000: 21) mengatakan, "political power is social power focused on the state. It involves others men for the purpose of influensing the behavior of the state, its legislative, administrative and judicial activities. "Aquinas, dalam Magniz-Suseno (1995: 5) berpandangan bahwa tidak ada seorang manusia yang secara asali mempunyai wewenang atas manusia lain, namun yang berwenang hanyalah satu yaitu Sang Hyang Wenang atau Sang Pencipta yakni Allah. Aspek violasi memang hampir selalu ada dalam politik, namun tidak harus membuat putus asa siapa pun yang ingin terlibat dalam mengusahakan kesejahteraan bersama melalui politik praktis yang terkadang keras. Konflik memang harus ada dalam politik supaya memunculkan konsensus yang rasional. Prinsip untuk menghasilkan konsensus yang rasional adalah konflik politik tidak destruktif terhadap individu dan kehidupan bersama, tidak dikendalikan oleh kepentingan penguasa, melainkan terarah pada pencapaian kebenaran demi kesejahteraan umum.

Keenam, aspek etika Levinas, yaitu panggilan primordial manusia. Levinas adalah filsuf keturunan Yahudi yang lahir pada tahun 1912 (MagnisSuseno, 2006: 85-86). Levinas menunjukkan bahwa secara primordial, manusia dalam segala penghayatan dan sikap-sikapnya didorong oleh sebuah impuls etis, oleh tanggung jawab terhadap sesama. Tanggung jawab primordial adalah dorongan dasar segala perhatian dan keprihatinan manusia. Impuls etis primordial terjadi dalam keseharian yaitu ketika berjumpa dengan orang lain. Wajah orang lain mengimbau atau berseru, "jangan bunuh saya” (Magnis-Suseno, 2006: 8588). Orang lain menyatakan diri melalui muka sebagai yang betul-betul berbeda atau lain dari seseorang. Realitas fisik muka yang berbeda menunjukkan bahwa muka tidak dapat dikuasai, dipegang, apalagi diperbudak. Ketelanjangan muka manusia juga menyingkapkan bahwa muka tidak mempunyai kekuasaan, malahan muka mengimbau untuk 'jangan membunuh'. Manusia harus menghormati, dan memandang muka itu sebagai produsen nilai-nilai kehidupan yang harus dihayati (Magnis-Suseno, 2006: 89). Politik, sebagai ilmu sosial, mesti menunjukkan aspek etika Levinas, yaitu melaksanakan apa yang tertulis dalam hukum tata 
negara berdasarkan kesadaran sosial yang mendasar dari manusia yakni tanggung jawab terhadap sesama, yaitu mengasihi.

Ketujuh, aspek hukum yaitu sebagai alat untuk mendamaikan kegiatankegiatan dan perilaku manusia dengan prinsip-prinsip ideal yang telah disepakati bersama (Paul, 1993: 56). Fletcher, dalam Magnis-Suseno (2006: 111-113), berpandangan bahwa tidak ada norma umum, karena setiap peristiwa adalah unik. Setiap peristiwa atau persoalan membutuhkan perlakuan tertentu. Fletcher, dalam Magnis-Suseno (2006: 113) mengakui satu hukum moral yaitu cinta kasih. Hukum berisi perintah dan larangan. Perilaku diklaim baik sejauh diperintahkan, dan buruk sejauh dilarang. Hukum atau aturan belum tentu benar karena diperintahkan dan belum tentu salah karena dilarang. Penerapan hukum harus memperhatikan konteks dan nilai-nilai mutlak seperti kasih, keadilan, kemanusiaan (Riyanto, 2011: 82). Indonesia memang negara hukum, tetapi harus diingat bahwa kata negara hukum diambil dari terjemahan filsafat politik 'office of justice' (tata keadilan), sehingga negara hukum tidak berarti negara penuh hukum, melainkan hukum selalu demi artikulasi pembelaan tata keadilan bagi semua (Riyanto, 2011: 84). Aquinas, dalam Sumaryono (2002: 31-50) mendefinisikan hukum sebagai tata akal budi (ordo rationis). Hukum lahir dari realitas bahwa manusia, dengan akal budinya ditugaskan oleh Tuhan untuk menata kebersamaannya dengan yang lain secara indah, baik, dan adil.

\subsection{Konstitusi Gaudium et Spes}

\subsubsection{Gambaran Konstitusi Gaudium et Spes}

Gaudium et Spes merupakan salah satu dokumen ASK. Konstitusi GS adalah dokumen khusus ASK dalam Konsili Vatikan II yang merumuskan panggilan Gereja dalam dunia modern. Kata "Gaudium et Spes”, diterjemahkan dalam bahasa Indonesia menjadi "Kegembiraan dan Harapan”. Judul konstitusi tersebut ingin mengungkapkan bahwa Gereja menyajikan dirinya yang harus berbagi kegembiraan dan harapan, penderitaan dan kegelisahan dengan sesama sezaman (GS. 1). Ada dua bagian GS: (1) berisi refleksi teologis, konsep, pertimbangan hubungan Gereja dan dunia agar tata dunia mengarah kepada kehendak Allah; (2) jawaban Gereja terhadap masalah yang mendesak: perkawinan dan keluarga, kebudayaan, kehidupan ekonomi, sosial dan politik, serta tentang damai dan perang (DKV., 1993: XIII- XIV).

\subsection{Politik Praktis menurut Gaudium et Spes}

Nama konstitusi Gereja menggarisbawahi suatu inti ajarannya. Nama salah satu konstitusi yang dihasilkan para bapa Konsili Vatikan II yang berkaitan dengan kehadiran Gereja di zaman modern adalah Gaudium et Spes, yang berarti Kegembiraan dan Harapan (GS. 1). Kegembiraan dan duka dunia adalah 
kegembiraan dan duka Gereja sebagai murid Kristus yang dibimbing oleh Roh Kudus dalam peziarahan. Gereja diberi amanat oleh Allah untuk mewartakan kabar gembira keselamatan sesuai dengan kemampuan yang dianugerahkan Allah (GS. 1). Konstitusi GS mengamanatkan kepada segala bangsa secara khusus kepada umat Kristiani bahwa manusia harus diselamatkan. Satu-satunya cara Gereja menyelamatkan manusia adalah menjalin temu-wicara dengan dunia, hadir dalam dunia berdasarkan terang Kristus (GS. 3). Umat Katolik harus mengetahui dan merasakan kegelisahan-kegelisahan Gereja yang melatarbelakangi pentingnya Gereja khususnya kaum awam terlibat dalam politik praksis.

Kegelisan pertama adalah realitas perubahan-perubahan situasi yang mendalam dari tata dunia yang lebih statis ke visi yang lebih dinamis dan bercorak evolusioner; dari tata masyarakat komunitas tradisional ke masyarakat industrial yang mengubah pengertian-pengertian dan kondisi hidup kemasyarakatan. Perubahan-perubahan tersebut menjadikan norma, nilai moral tidak selalu cocok dihidupi zaman sekarang (GS. 5-7). Kedua, Konstitusi GS menunjukkan kepada umat Katolik adanya ketidakseimbangan teoritis dengan praktis, antara moralitas suara hati dengan pembawaan diri pada situasi konkret keseharian pada zaman sekarang. Ketiga, pertentangan sengit antara pelbagai lapisan masyarakat, dan adanya ambisi memperjuangkan ideologi tertentu atau ideologi bangsa-bangsa lain menjadi pemicu konflik hidup bersama. "Itu semua membangkitkan sikap saling tidak percaya dan bermusuhan, konflik-konflik dan kesengsaraan, yang sebabnya dan sekaligus korbannya ialah manusia sendiri” (GS.8).

"Gereja tidak bisa lagi hanya berurusan dengan hal-hal rohani, spiritual, dan liturgis, seakan-akan persoalan yang dialami masyarakat bukan urusan Gereja, dan urusan Gereja hanyalah sebatas di seputar gedung gereja” (Dewantara, JPAK, 18.8.2017: 13).

Umat Katolik harus peduli dan sedapat mungkin terlibat dalam kehidupan politik praktis demi kebaikan umum menuju keselamatan kekal sebagai keluarga di dalam Tuhan sejak di dunia ini.

\subsubsection{Dasar Ajaran Politik Praktis menurut Gaudium et Spes}

Dasar politik praktis menurut GS ada empat yaitu visi Gereja tentang martabat manusia, masyarakat manusia, kegiatan manusia di seluruh dunia, dan nilai kerja manusia. Pemahaman Gereja akan dasar berpolitik sangat penting dipahami sebagai satu kesatuan.

Pertama, pandangan Gereja tentang martabat manusia. Protagoras, dalam Sudiarja (2006: 1127-1130) memahami manusia sebagai norma dari segalasegalanya. Filsuf abad modern pada umumnya sangat menekankan aspek 
rasionalitas manusia (Hardiman, 2004: 2-7). Konsepsi lain tentang manusia adalah sebagai makhluk yang lemah, absurd, tidak ada alasan mengapa manusia ada dan ke mana tujuannya, seperti yang dipikirkan oleh Arthur Schopenhauer (Bertens, 2000: 117-122). Optimisme ekstrim dan pesimisme ekstrim tentang manusia sangat memengaruhi pola relasi sosial-politik saat ini. Gereja, melalui GS mengatasi pandangan optimisme dan pesimisme ekstrim tentang manusia dengan terang inkarnasi Kristus (GS. 12). Gereja mengimani bahwa Yesus Kristus telah wafat dan bangkit bagi semua orang di hadapan persoalan hidup bersama.

Gereja mengimani bahwa manusia merupakan citra Allah. Kristus adalah gambaran asali manusia. Misteri manusia terungkap dalam diri Kristus sebagai manusia sepenuhnya dan sekaligus Allah sepenuhnya, meskipun misteri manusia dan Yesus belum sepenuhnya terpahami. Kitab Suci mengajarkan bahwa manusia diciptakan secitra dengan Allah karena dianugerahi akal budi, kebebasan, martabat, dan berbagai kemampuan lain untuk mengenal Allah. Manusia dimohon menjadi rekan sekerja Allah (Sinaga, Forum, No. 2/2014: 39-40). Allah menetapkan manusia sebagai tuan atas semua makhluk di dunia karena manusia adalah citra Allah (GS. 12).

Allah tidak menciptakan manusia seorang diri. Allah memberikan kepada Adam seorang penolong yakni Hawa. Tindakan Allah memberi penolong kepada Adam mengungkapkan kehendak Allah supaya manusia hidup bersekutu (Kej. 1: 27-28; 2: 18). Manusia, menurut kodratnya yang terdalam bersifat sosial. Manusia, tanpa relasi positif dengan sesama tidak dapat berkembang ke arah yang benar (GS. 12). Sifat sosial manusia juga menunjukkan suatu sisi kelemahan manusia yang selalu membutuhkan orang lain dan Allah.

Martabat manusia yang mampu mengenali Allah menemukan diri juga sebagai makhluk yang mudah terpengaruh oleh bujukan setan untuk berbuat jahat dan menolak Allah penciptanya. Relasi manusia dengan Allah dirusak oleh keinginan manusia sendiri untuk mencari tujuan lain di luar Allah (GS. 13). Tindakan manusia menolak Allah disebut perbuatan dosa. Perbuatan dosa yang melukai hati Allah bukan pertama-tama dari ungkapan penghinaan manusia secara verbal dan langsung kepada Allah atau melanggar hukum Allah, melainkan perbuatan manusia yang melukai relasi sosial dan menodai keluhuran martabat manusia sendiri, yang dengan sendirinya telah melanggar hukum abadi Allah.

Manusia harus dikembalikan kepada kodratnya sesuai tujuan penciptaannya dalam kesatuan jiwa (batin) dan raganya (GS.14). Manusia perlu mengikutsertakan badannya dalam upaya mencapai kesempurnaan hidup yang sesungguhnya di dalam Allah. Manusia harus meluhurkan Allah dalam badannya (GS. 14). Kodrat manusia merupakan percikan kodrat Allah yang terungkap (1) dalam terang akal budi manusia yang melampaui seluruh alam (empiris), dan (2) dalam kehausan jiwa manusia mencari kebenaran terdalam, maupun ketertarikan 
budi manusia untuk mencari dan mencintai apa yang serba benar dan baik (GS. 15). Manusia dipanggil untuk hidup bahagia bersama Allah sebagai satu keluarga (KGK. 356).

Gereja, melalui GS juga mengajarkan tentang hati nurani. Keagungan dan kodrat manusia terdapat juga dari adanya hati nurani. Manusia berada seorang diri dengan Allah di dalam hati nuraninya, yang sapaan-Nya menggema dalam batin (GS. 16).

"Atas kesetiaan terhadap hati nurani umat Kristiani bergabung dengan sesama lainnya untuk mencari kebenaran, dan untuk dalam kebenaran itu memecahkan sekian banyak persoalan moral, yang timbul baik dalam hidup perorangan maupun dalam hidup kemasyarakatan” (GS. 16).

Hati nurani adalah hukum Ilahi dimana Allah mendorong manusia untuk mengambil keputusan dengan memilih apa yang baik, terpuji dan benar terhadap tindakan yang jahat, keliru dan sesat (GS. 16). Hati nurani ialah inti manusia yang paling rahasia, sanggar sucinya. Manusia pun diadili oleh Allah lewat hati nurani manusia. Ketaatan umat Katolik terhadap hati nurani tidak seperti ketaatan orang pada umumnya. Umat Katolik wajib taat kepada hati nurani bila menyuarakan pilihan dan tindakan yang sesuai dengan nasehat Injili atau ajaran Kristus sebagai jalan, kebenaran dan hidup (Yoh. 14: 6). Keputusan untuk bertindak, bertutur kata, dan berkehendak seperti Kristus merupakan syarat mutlak suara hati tidak dapat sesat. Umat Kristiani harus bertindak seperti Kristus, menjadi alter Kristus, Kristus yang menjelma dalam pribadi pelaku nilai-nilai Injili.

Konstitusi GS mengajarkan tentang kebebasan. Kebebasan merupakan tanda mulia dan gambar Allah dalam diri manusia yang ikut menentukan martabat manusia. Manusia mencari penciptanya secara bebas, artinya manusia bertindak menurut pilihannya yang sadar terhadap kebaikan, kebenaran dan keindahan. Kebebasan yang hakiki dicapai dengan jalan melepaskan diri dari nafsu-nafsu tidak teratur, yang melawan prinsip suara hati, kesadaran manusia, dan kebijaksanaan Allah (GS. 17). Tindakan menipu, salah, bodoh dan mengingkari suara hati yang murni Ilahi, serta melakukan tindakan atas dasar kebebasan yang tidak bertanggunjawab merupakan penolakan manusia terhadap kodratnya sendiri sebagai makhluk yang luhur dalam rancangan Allah. Arenth, dalam Pandor (ARETE, No. 01/02/ 2013: 6-9), mengatakan bahwa politik tidak dapat dipahami dalam kategori dominasi atau penguasaan, melainkan dalam kategori kebebasan.

Konstitusi GS pun mengajarkan tentang rahasia maut. Manusia mengalami katakutan akan maut, sehingga mengupayakan berbagai cara untuk menghindari maut. Ketakutan manusia terhadap maut, penderitaan fisik sesungguhnya mengungkap misteri manusia sebagai makhluk yang berasal dari keabadian, namun sering manusia menganggap yang fana sebagai jaminan hidup yang 
sejahtera dan abadi. Manusia sering mengekalkan diri di dalam barang-barang yang fana padahal hanyalah kesemuan belaka. Benda fana hanyalah sarana untuk mencapai martabat manusia yang luhur di dalam Allah. Tuhan telah menanamkan benih keabadian yang ditandai oleh akal budi manusia, oleh kehausan terhadap kebenaran terdalam, keabadian dan kebebasannya mengenal dan mengasihi Allah penciptanya (GS. 17).

Gereja, melalui GS mengungkapkan bahwa Kristus merupakan penyingkapan rahasia panggilan manusia yang luhur. Peristiwa inkarnasi Kristus mengungkapkan banyak misteri, diantaranya Allah yang mahaagung, mahabijaksana telah bekerja dengan menggunakan akal budi manusiawi, bertindak atas kehendak manusiawi dan mengasihi dengan hati manusiawi (GS. 22). Umat Kristiani harus menggunakan pikirannya, kehendaknya dan hatinya untuk mengabdi sesama seperti cara Kristus sendiri mengabdi manusia. Cara orang Kristiani mengabdi kepada kepentingan umum tidak bisa dilepaskan dari Kristus, malahan harus bersumber dari Kristus dan menuju kepada Kristus.

Dasar keterlibatan Gereja dalam hidup politik praktis juga berangkat dari paham Gereja tentang masyarakat manusia. Manusia dipanggil kepada kesempurnaan dalam persekutuan. Allah merencanakan memanggil manusia sebagai satu keluarga dalam persaudaraan menuju Allah sendiri (GS. 24). Hukum yang harus dihayati dalam sosialitas adalah cinta kasih (GS.24). Fichte, dalam Wiej (2000: 99), berkeyakinan bahwa hidup yang sungguh-sungguh ialah mencintai sesama manusia. Kitab Suci mengajarkan bahwa kasih terhadap Allah tidak terpisah dari kasih terhadap sesama (Roma 13:9-10; 1 Yoh. 4: 40). Yesus sendiri menghendaki semua orang menjadi satu dalam Allah (Yoh. 17:21-22).

Manusia yang mengusahakan terwujudkan kesejahteraan bersama adalah manusia yang ambil bagian dalam tugas Allah untuk mensejahterakan manusia. Manusia memuliakan Allah dan menguduskan diri sendiri melalui keterlibatan membangun kesejahteraan bersama (AA. 4). Kewajiban suci setiap orang saat ini adalah kewajiban sosial sebagai tugas yang harus dipatuhi. Umat Kristiani harus dididik supaya berjiwa sosial yang benar dan diwujudkan dalam kehidupan bersama secara khusus dalam urusan-urusan kenegaraan. Setiap umat harus menemukan nilai-nilai yang menarik dan membangkitkan gairah melayani sesama (GS. 31).

Manusia saling tergantung satu sama lain dalam mencapai tujuan pribadinya. Ikatan-ikatan sosial yang diperlukan manusia bagi pertumbuhan manusia dan tercapainya tujuan hakiki adalah keluarga, masyarakat politik. Di balik dampak positif dari ikatan sosial terdapat gangguan yang sering timbul di bidang kemasyarakatan, struktur-struktur ekonomi, politik dan sosial (GS. 25). Ketergantungan manusia dengan sesama harus ada dalam maksud kesejahteraan umum (GS. 26). Kesejahteraan umum adalah keseluruhan kondisi-kondisi hidup 
kemasyarakatan yang memungkinkan baik kelompok maupun anggota-anggota perorangan, untuk secara lebih penuh dan lebih lancar mencapai kesempurnaan (GS. 26). Kesejahteraan umum menjadi tujuan utama politik dan tujuan keterlibatan Gereja dalam dunia. Kesempurnaan dan kemajuan hidup masyarakat akan mudah dicapai dengan tiada hentinya menunjang kesejahteraan pribadipribadi. Penataan sistem politik harus bertujuan untuk kesejahteraan individu setiap warga negara, dan kesejahteraan bersama bukan demi hukum. Sistem politik untuk manusia, sama seperti hari sabbat untuk manusia (Mrk. 2: 27-28). Efektivitas dan efisiensitas pencapaian bonum commune terletak pada tata dunia yang harus bertumpuh dalam kebenaran, dibangun dalam keadilan, dihidupkan dalam cinta kasih.

Kehendak untuk menata hidup bersama adalah sikap hormat terhadap pribadi manusia sebagai ‘dirinya yang lain’ (GS. 27; Dister, 2004: 169). Sikap hormat pada pribadi manusia harus diperluas kepada mereka yang menganggap diri sebagai lawan supaya dapat dengan mudah menjalin dialog dalam bidang sosial, politik, ataupun keagamaan sembari tetap berpegang pada kebenaran dan kebaikan bersama. Sikap hormat kepada pribadi manusia menjadi senjata untuk menumpas individualis dan totalistis sehingga memungkinkan terwujudnya prinsip partisipasi bagi bonum commune yang dikehendaki Gereja (Pandor, ARETE, No. 01.02.2013: 52-53).

Dasar lain keterlibatan politik praktis menurut GS berangkat dari penilaian Gereja terhadap kegiatan atau kerja manusia di seluruh dunia. Kegiatan manusia di seluruh dunia dilihat dari maknanya bagi kehidupan bersama. Gereja menilai kegiatan manusia seiring penilaian positif terhadap realitas duniawi, secara khusus kegiatan politik praktis (Olla, 2014: 53). Gereja melihat makna kerja tidak hanya sekadar sarana untuk memenuhi kebutuhan ekonomis, namun sebagai sarana menjauhkan jiwa manusia dari kejahatan. Dasar biblis pandangan positif Gereja tentang kerja berangkat dari paham bahwa manusia diciptakan secitra dengan Allah dan diberi tanggung jawab untuk menaklukkan bumi. Pemberian tanggung jawab oleh Allah kepada manusia inilah yang menjadikan kerja memiliki motivasi rohani. Politik adalah wadah kerja yang memiliki nilai rohani dan wadah menyucikan hidup. Karya manusia memperlihatkan keagungan Allah. Kerja menjadi pendukung kehidupan bersama, sarana mengubah diri sendiri, dan memanusiakan manusia. Politik praktis menjadi medan keterlibatan dan pelaksanaan kasih (Olla, 2014: 54-55).

\subsubsection{Alasan Berpolitik Praktis Menurut Gaudium et Spes}

Ada empat alasan mendasar Gereja terlibat dalam kehidupan politik praktis. Pertama, Gereja mengimani bahwa Tuhan Yesus telah wafat dan bangkit bagi semua orang dari segala zaman (GS. 10). Kedua, Gereja sungguh yakin 
bahwa manusia diciptakan secitra dengan Allah, oleh karena itu, manusia adalah tujuan pada dirinya (GS. 12). Ketiga, manusia diciptakan tidak sendiri, melainkan bersama dengan sesama. Manusia dipanggil Allah untuk hidup bersekutu denganNya sebagai satu keluarga. "Dari kodratnya yang terdalam manusia bersifat sosial; dan tanpa berhubungan dengan sesama, ia tidak dapat hidup dan mengembangkan bakat-pembawaannya” (GS. 12).Keempat, kodrat manusia ditentukan oleh unsur jiwa dan raganya, oleh kondisi-kondisi badaniahnya yang Allah anugerahkan seperti akal budi untuk mencapai kebijaksanaan dan kebenaran, dan hati nurani sebagai sumber hukum yang seharusnya ditaati manusia. Daya-daya pemberian Allah tersebut digunakan untuk mengasihi, untuk mengusahakan kesejahteraan umum.

\subsubsection{Hidup Menegara dan Menggereja}

Hakekat dan tujuan negara adalah untuk kesejahteraan para warganya. Pengabdian kepada manusia secara manusiawi, adil dan berkebaikan hati menampakkan hakekat dan tujuan negara yaitu bonum commune (GS. 74). Sumbangan Gereja bagi politik praktis ada dua bentuk: (1) memberikan prinsip moral kekuasaan agar kekuasaan dijalankan berlandaskan cinta kasih, kebenaran dan keadilan; (2) umat (khususnya awam) diharapkan terlibat secara langsung dalam politik praktis dengan menghayati Injil, membawa pembebasan pada ketidakadilan, penindasan, intoleransi dan dehumanisasi. Agama pada tahap good life, terutama tahap weltanschauung tidak bisa dibatasi pada ruang privat, melainkan harus mengintervensi ruang publik dengan memanfaatkan dokumendokumen dan tradisinya untuk menghadirkan intuisi moral bagi diskursus publik. Negara dan agama, meskipun berbeda, harus melayani manusia yang sama (Menoh, 2015: 124).

\subsubsection{Politik sebagai Persoalan Mendesak bagi Gereja}

Gereja harus membantu institusi duniawi sejauh tergantung padanya dan misinya. Misi yang paling diinginkan Gereja adalah misi untuk mengabdi kepada kesejahteraan semua orang, mengembangkan diri dengan bebas di bawah pemerintahan mana pun, yang mengakui hak-hak pribadi dan keluarga serta kebutuhan-kebutuhan akan kesejahteraan umum (GS. 42). Umat Kristiani harus menyinari dunia dengan terang Injil, dan menjadi saksi di dalam dunia. Wogaman (2000: 227), mengatakan:

"To be a Christian human being is to be active, creative, even assertive. When Christian mistakenly allow the denial of their own basic civil rights (such as freedom of speech, freedom of the press, freedom of worship, freedom from artibitrary arrest and detainment, and the right to vote) they weaken such rights for others.” 
Kutipan di atas menegaskan bahwa hak asasi manusia seperti berbicara (tentang kebenaran), kebebasan beribadah, kebebasan pers, dan lain sebagainya adalah hak sipil yang menjadikan seorang semakin Kristiani. Semua hak sipil manusia menunjang kesejahteraan umum.

Kedua, umat Kristiani harus menyinari dunia dengan terang Injil dan menjadi saksi di dalam dunia. Para uskup bekerjasama dengan para imam untuk menyiarkan warta Kristus agar kegiatan-kegiatan Kristiani dilimpahi cahaya Injil (GS.43). Umat yang mengembangkan masyarakat berdasarkan rencana Allah dalam tata politik, baik tingkat nasional dan internasional menyumbang bantuan hal-hal lahiriah yang besar kepada Gereja (GS. 44). Kaum awam berperan sebagai aktor dalam membangun kesejahteraan umum.

Tuhan menciptakan manusia untuk hidup bersama, berkehendak menyelamatkan semua manusia, membentuk semua manusia menjadi umat-Nya yang suci (GS. 35). Oleh karena itu, keselamatan bagi semua orang adalah tanggung jawab utama Kristiani dalam politik praktis. Hukum yang harus dihayati umat Katolik adalah hukum kodrat dan hukum Injil.Hukum kodrat adalah tatanan sipil yang berpedoman pada tata penciptaan Tuhan (Iman Katolik, 1996: 97). Hukum Injil adalah cinta kasih (GS. 74). Sikap penguasa (pemimpin/elit politik) haruslah memberikan ruang yang leluasa kepada perorangan maupun kelompok sebagai pengantara; mengembangkan ruang kegiatan warga negara. Masyarakat juga memiliki tanggung jawab mengawasi jalannya hukum, kekuasaan, dan memupuk rasa cinta tanah air melalui berbagai ikatan antar suku, antar bangsa, dan antar negara (GS. 75).

\subsection{Politik Praktis sebagai Wadah Pengudusan Hidup bagi Kaum Awam}

Gereja mengakui politik sebagai jalan kesucian (Olla, 2002: 68). Panggilan kepada kesucian sudah harus dialami sejak di dunia ini. Politik merupakan jalan kesucian yang disadari dihayati dengan bentuk-bentuk spiritualitas politik Kristiani: Spiritualitas historis-inkarnatif, yaitu keyakinan bahwa Allah masuk dalam sejarah konkrit manusia untuk menyelamatkannya secara integral (Olla, 2002: 58). Keyakinan akan penyelamatan Kristus tidak dapat dibatasi dalam lingkup pengalaman interior atau batiniah saja, melainkan mesti masuk dalam dimensi sosial-politik. Kedua, spiritualitas kasih-inspiratif yaitu semangat umat untuk terlibat dalam sosial-politik berdasarkan kasih (Olla, 2002: 63). "Spiritualitas politik yang didasarkan pada kasih menjadi sumber pencerahan dalam menghadapi masalah-masalah sosial politis” (Olla, 2002: 64). Ketiga, spiritualitas bela rasa-memihak: semangat melayani masyarakat khususnya yang kecil dan tertindas (Olla, 2002: 63). Sikap dan seluruh hidup Yesus adalah inspirasi bagi spiritualitas politik yang berbela rasa dan bersifat memihak kaum tertindas (Olla, 2002: 65). 
Politik praktis akan menguduskan hidup bila politik yang dilaksanakan mewujudkan iman yang sekuler; mengusung nilai-nilai moral, dan mediasi politik; berasal dari dorongan cinta akan keadilan dan perdamaian; politik harus mengabdi kepentingan umum; dan kekuasaan harus digunakan untuk melayani dengan sepenuh kasih. Setiap politikus Kristiani harus belajar dari kepemimpinan Yesus yang melayani.

\section{HASIL PENELITIAN}

Metode penelitian yang digunakan adalah metode kualitatif. Data hasil penelitian telah dikumpulkan dengan cara wawancara terbuka. Wawancara dilakukan dengan responden pilihan. Sampel penelitian adalah beberapa umat Katolik Madiun yang menjadi anggota DPRD kota Madiun, para aktivis Ormas Katolik seperti PMKRI, WKRI, serta umat yang berkecimpung di dunia birokrasi pemerintahan. Peneliti menengarai pemahaman umat Katolik Madiun terhadap Konstitusi GS dalam kehidupan politik Praktis.

Responden penelitian berjumlah 8 (delapan) orang yang terdiri dari 2 (dua) anggota DPRD Madiun; 1 (satu) orang anggota partai politik dan aktivis sosial dan budaya; 1 (satu) orang akademisi, aktivis HAM dan anggota partai; 1 (satu) orang tenaga akademisi sekaligus sebagai pembina ormas Katolik dan pengembangan masyarakat Madiun dan Surabaya; 1 (satu) orang penyelengga negara (Bawaslu) kota Madiun; 1 (satu) orang birokrat pemerintah yaitu sebagai Sekretaris 1 KesBangPol Madiun; dan 1 (satu) orang pengurus WKRI. Berdasarkan varian latar belakang responden yang ada sangat menentukan kualitas informasi data.

Responden yang telah dipilih memiliki kredibilitas dalam menjawab masalah dan tujuan dalam penelitian ini. Pengetahuan tentang politik dimiliki oleh semua responden meskipun tidak semua memiliki latar belakang pendidikan politik atau hukum tata negara secara formal, namun para responden memiliki pengalaman yang kaya dalam keterlibatan dengan sosial-politik praktis. Sebagian besar dari responden memiliki posisi yang sangat strategis di Kota Madiun baik sebagai anggota DPRD Kota Madiun, birokrat, anggota partai, aktivis dan akademisi, maupun aktif di LSM dan Ormas lainnya. Para responden juga memiliki dan memegang posisi penting di berbagai organisasi penting baik organisasi intra maupun ekstra Gereja. Perbedaan etnis dan asal daerah kelahiran para responden pun sangat memperkaya panorama data penelitian, sebab para responden yang ada berasal dari etnis Tionghoa, Flores, Jawa Tengah, dan dari Jawa Timur. Semua responden berdomisili di Madiun dan berada dalam wilayah teritorial Gereja Katolik Madiun.

Hasil analisa kualitatif mengenai pemahaman politik menunjukkan tiga data penting. Pertama, terdapat $7(87,5 \%)$ responden memahami politik sebagai 
cara atau sistem mengatur hidup bersama; 5 (62,5\%) responden mengerti politik sebagai ilmu yang berbasis pada masyarakat dan bertujuan untuk masyarakat; dan 5 (62,5\%) responden mengerti politik sebagai cara meraih kekuasaan. Kedua, data analisa kualitatif mengenai awal mula mengenal politik praktis menunjukkan bahwa 8 (100\%) mengenal politik praktis pertama di dunia pendidikan (sejak masuk sekolah, masuk organisasi-organisasi sekolah dan organisasi di perguruan tinggi); 4 (50\%) responden mengenal politik melalui organisasi Gereja; 2 (25\%) responden mengenal melalui pengkaderan dari tokoh politik Katolik dan dari tokoh anggota partai; 1 (12,5\%) responden mengenal politik lewat media sosial. Ketiga, data analisa kualitatif mengenali keterlibatan politik praktis menunjukkan bahwa 4 (50\%) responden terlibat politik melalui politik praktis (organisasi LSM, PUSKAT, Karang Taruna, kemasyarakatan; menyisihkan waktu untuk kegiatan sosial kemasyarakatan; menjadi pemimpin di tengah masyarakat baik pada tingkat mikro ataupun makro); 3 (37,5\%) terlibat politik praktis karena adanya motivasi yaitu adanya background organisasi yang kuat, dan inspirasi model politik yang baik, kegelisahan terhadap polarisasi pilpres, dan ketimpangan sosial.

Hasil analisa data kualitatif mengenai reflektivitas terhadap praktek politik dalam birokrasi pemerintah menunjukkan bahwa 8 (100\%) responden menganggap birokrasi politik saat ini adalah sesuatu yang buruk (biaya politik tinggi, hanya digunakan untuk memperkaya diri, usaha mengembalikan modal, masyarakat dan umat apatis, politik yang tidak dewasa); 4 (50\%) responden mengatakan birokrasi politik sesungguhnya sesuatu yang baik (politikus memiliki pengetahuan yang berpihak pada kesejahteraan masyarakat, politik dijadikan alat untuk mencapai tujuan yang baik, jabatan politik memiliki program untuk mengangkat martabat manusia, elemen bangsa yang powerful digunakan untuk kemajuan bersama, pemimpin sungguh mengabdi untuk kepentingan masyarakat); 2 (25\%) responden memberikan solusi untuk menuju politik yang baik: mendewasakan masyarakat pemilih, melakukan restorasi semangat awal pendiri bangsa, dan melakukan perubahan yang berprinsip pada akuntabel, bertanggung jawab dan tidak korup.

Hasil analisa data kualitatif mengenai pengetahuan tentang GS, dan ajarannya menunjukkan bahwa 8 (100\%) responden mengenal GS meskipun tidak semua memahami secara mendalam; 6 (75\%) responden memahami dasar ajaran GS yaitu panggilan berdasarkan iman, hati nurani dan moralitas Gereja untuk berpartisipasi dalam kehidupan sosial; 5 (62,5\%) responden mengerti bahwa isi GS adalah Gereja harus bertanggung jawab terhadap kehidupan bermasyarakat di dunia (terjun ke masyarakat, hidup realistis, membangun komunikasi dengan masyarakat, menghormati, menghargai, toleransi, mengambil peran aktif di masyarakat); 2 (25\%) responden memahami tujuan keterlibatan Gereja adalah 
bonum commune (kesejahteraan umum, kemaslahatan seluruh umat manusia, ambil bagian di masyarakat).

Hasil analisa data kualitatif mengenai ajaran politik Gereja seturut GS menunjukkan bahwa 6 (75\%) responden menyatakan, tujuan utama Gereja berpolitik praktis adalah untuk bonum communeyakni kepekaan terhadap masyarakat, terlibat secara bertindak etis, menata dunia sesuai dengan kehendak Allah (sistem pemerintahan harus memanusiakan manusia); 3 (37,5\%) responden memahami bahwa ajaran GS tentang politik termuat dalam hubungan Gereja dengan masyarakat (Gereja membangun relasi baik dengan dunia supaya dapat membangun citra politik yang baik); 3 (37,5\%) responden menyatakan bahwa ajaran politik dari GS terungkap dalam maksud rencana pengkaderan; 2 (25\%) responden menyatakan bahwa ajaran politik Gereja menurut GS adalah bonum commune.

Hasil analisa data kualitatif mengenai cara menghayati ajaran Gereja seturut GS menunjukkan bahwa 6 (75\%) responden mengatakan, cara menghayati GS adalah dengan terjun dalam politik praktis; 4 (50\%) responden mengatakan, GS dapat dihayati dengan terlibat di dunia politik sebagai panggilan dan perutusan dari Gereja; 3 (37,5\%) responden mengatakan, politik yang dijalankan harus berorientasi pada bonum commune; 2 (25\%) responden mengatakan, berpolitik menurut GS harus berdasarkan pada keutamaan dan nilai Kristiani; 1 (12,5\%) responden mengatakan, cara menghayati GS adalah memanfaatkan hak pilih dengan bijaksana.

Hasil analisa data kualitatif mengenai tanggung jawab awam Katolik dalam kehidupan praktis seturut GS menunjukkan bahwa 7 (87,5\%) responden mengatakan, tanggung jawab kaum awam dalam politik adalah tanggung jawab sosial dan moral; 6 (75\%) responden mengatakan, tanggung jawab kaum awam dalam politik praktis adalah tanggung jawab kepada diri sendiri dan iman; 3 (37,5\%) responden mengatakan, tanggung jawab kaum awam dalam politik praktis adalah tanggung jawab pendidikan politik. Hasil analisa data kualitatif mengenai tantangan mewujudkan politik praktis seturut GS menunjukkan bahwa $5(62,5 \%)$ responden mengatakan tantangan terbesar muncul dari pribadi yang beriman; 3 (37,5\%) responden mengatakan, tantangan politik sesuai GS adalah konstruksi sosial (maraknya politik uang dan politik identitas, hidup yang menilai hanya dari materi dan bukan dari integritas).

Hasil analisa data kualitatif mengenai harapan bagi politik praktis seturut GS menunjukkan bahwa 7 (87,5\%) responden berharap kepada Gereja (realistis dalam menghadapi tantangan sosial dengan mendorong umat terlibat dalam kehidupan politik praktis; mengajar dan membina politikus, guru, PNS, dosen berbasis data; dan mendukung mereka yang ingin terlibat politik praktis); 7 $(87,5 \%)$ responden menaruh harapan terhadap politikus Katolik (menjadi 
pembaharu politik dan pengantara Gereja dengan masyarakat; menjadi pengkader generasi muda; mewarnai legislatif dengan bonum commune; memperjuangkan keadilan; kritis terhadap kebijakan; memperjuangkan eksistensi sekolah Katolik; mampu menyusun hukum yang baik; menyadari jabatan politik sebagai pengabdian; tidak menyimpang dari ajaran Gereja, dan mampu bekerja sama; selalu memurnikan motivasi keterlibatan sosial-politik; memiliki kelompok aspirasi dan program untuk bertemu dengan berbagai kalangan umat; berkarya, hidup menggereja serta bermasyarakat, baik, pintar, dan sederhana); 5 (62,5\%) responden berharap kepada kaum klerusmempunyai waktu diskusi dengan aktivis dan politikus Katolik, memberikan restu kepada umat yang berpolitik praktis, imam dan DPP sadar bahwa kehidupan harus dijaga bersama, peduli terhadap aktivitas di luar altar, mempunyai program pengkaderan mulai dari keluarga sampai perguruan tinggi; 3 (37,5\%) responden sangat berharap kepada kaum awam keseluruhan supaya mereka yang dianggap mampu mau terlibat dalam politik, generasi muda berani berpolitik praktis, menghayati keterlibatan politik sebagai panggilan untuk mengabdi; 2 (12,5\%) responden mengharapkan agar pembinaan politik yang baik terjadi di lembaga pendidikan Katolik.

\section{KESIMPULAN}

Politik (menurut maknanya yang hakiki) merupakan cara menata hidup bersama dalam suatu masyarakat atau negara untuk mencapai kesejahteraan umum. Politik (sebagai ilmu) masuk dalam etika atau moral, sebab politik merupakan cabang pengetahuan praktis, yaitu cara menjalani hidup dalam kebersamaan dengan sesama. Politik tanpa moral menjadikan politik yang sangat buruk, menyengsarakan rakyat, terutama mereka yang miskin, lemah dan terlantar. Stigma politik sesuatu yang baik atau jahat tidak lepas dari kontestasi politik di ruang publik. Politik yang baik memiliki tantangan yaitu semangat utilitarianisme, aspek violatif, irasionalitas hukum, dan kaburnya tanggung jawab primordial yakni tanggung jawab kepada sesama.

Konstitusi GS merupakan salah satu dari belasan dokumen ASK yang merumuskan panggilan Gereja dalam dunia modern. Dasar ajaran politik Gereja adalah martabat manusia di hadapan Allah. Misteri manusia terungkap dalam diri Kristus sebagai manusia sepenuhnya dan sekaligus Allah sepenuhnya. Kesecitraan manusia dengan Allah terungkap dalam realitas manusia yang dianugerahi akal budi, kebebasan, martabat, hati nurani, melekatnya misteri maut, yangmemampukan manusia memilih menjadi rekan kerja Allah menata dunia. Gereja juga menempatkan dasar politik yang kokoh berdasarkan paham realitas masyarakat manusia yang dipanggil kepada kesempurnaan dalam persekutuan, dimana kasih adalah hukum utama sosialitas manusia. Dasar ketiga ajaran politik menurut GS adalah visi Gereja tentang makna kerja manusia di seluruh dunia, 
yakni kerja manusia bukan sekadar sarana untuk memenuhi kebutuhan ekonomis, namun sebagai sarana menjauhkan jiwa manusia dari kejahatan. Politik praktis merupakan salah satu wadah kerja yang menyucikan hidup.

Politikus Kristiani harus meneladan Kristus yang tidak hanya melaksanakan karya-karya karitatif, namun juga mematuhi hukum-hukum tanah air-Nya. Pengabdian kepada sesama bertujuan menyiapkan landasan bagi kemajuan surgawi, sehingga orang Kristiani bertanggung jawab membawakan suasana surgawi di dunia ini. Secara garis besar politikus Kristiani bertanggung jawab menetapkan dasar hukum negara, dan menentukan sistem serta hukum dan aturan-aturan pemerintahan yang berpihak pada bonum commune. Tantangan terbesar untuk mewujudkan politik yang baik ada pada pribadi politikus beriman Katolik itu sendiri, yaitu bagaimana menjadi konsisten mempertahankan identitas kekatolikan, berwacana dan berjuang untuk kepentingan umum, serta berani keluar dari zona nyaman. Oleh karena itu, Gereja harus membumi untuk menghadapi tantangan sosial dengan mendorong umat terlibat dalam kehidupan politik praktis supaya membersihkan politik yang sudah kotor; mengajarkan ASK di dunia pendidikan; membina politikus, guru, PNS, dosen dengan berbasis data sehingga mereka dapat menjadi garam dan terang dunia yang baik dan tepat. Harapan juga diarahkan kepada para politikus Katolik supaya menjadi pembaharu politik yang baik dengan komunikasi timbal-balik Gereja dengan masyarakat, menjadi pengkader generasi muda supaya berani terlibat politik praktis, mewarnai parlemen dengan undang-undang yang harus berpihak bagi bonum commune.

Mengetahui dan memahami inti ajaran GS tidak cukup untuk dapat memperjuangkan bonum commune dengan integritas tinggi. Gereja harus mengambil langkah untuk menginternalisasikan ASK sejak usia dini sebagai formatio jiwa sosial-politik anggota Gereja yang berbasis pada pastoral keluarga, pendidikan, lingkungan atau stasi, dan paroki, sehingga umat mempunyai basis organisasi yang kuat untuk peduli pada manusia. Kaum klerus harus memberikan dukungan nyata lewat pengkaderan yang selalu berdimensi sosial, merangkul aktivis sosial-politik umat Katolik Madiun supaya tidak berjuang sendiri dan tanpa roh. Gereja memberikan kesadaran supaya umat memiliki kesadaran sosial, tidak apatis dengan keadaan politik dimana pun berada. Gereja, pada intinya harus terlibat dalam kehidupan bermasyarakat, berbangsa dan bernegara dengan dasar moralitas yang baik demi bonum commune.

\section{PENUTUP}

Politik, secara teroritis, menurut maknanya yang hakiki merupakan cara menata hidup bersama dalam suatu polis supaya terbentuk kesejahteraan bersama. Politik yang pada hakekatnya luhur pasti memiliki tantangan: adanya semangat utilitarianisme, aspek violatif, irasionalitas hukum, dan kaburnya tanggung jawab 
primordial yakni tanggung jawab kepada sesama. Situasi keotik tidak membuat Gereja pupus harapan.Tujuan keterlibatan Gereja dalam dunia politik (praktis) adalah bonum commune, yang mempunyai dasar pada martabat manusia sebagai citra Allah, makhluk yang dianugerahi hati nurani, kebebasan; misteri maut, makhluk sosial dan persona, dan Kristus sebagai rahasia panggilan manusia yang luhur. Akal budi, suara hati, dan tubuhnya yang dipakai Allah dalam misteri inkarnasi menunjukkan bahwa manusia harus menata kebersamaannya dengan menyelaraskan akal budi, hati nurani dan seluruh dirinya dengan kehendak Allah.

Politik praktis seturut GS, sebagai ilmu, memberikan dasar-dasar ontologis politik (manusia dalam rancangan Allah), epistemologi yaitu politik seturut GS berdasar pada moralitas politik demi kemanusiaan, dan aksiologis yaitu politik seturut GS berdasar pada hakekat manusia di hadapan Allah yang harus terungkap dalam prilaku hidup sosial-politik sehari-hari. Pemahaman akan GS memberi inspirasipolitik praktis dalam kaca mata Gereja Katolik yang ada dalam GS sebagai ASK di zaman modern ini. Praktek politik dari politikus Katolik seharusnya selalu berdasarkan ajaran iman sejauh tidak mendiskriminasi manusia dalam bentuk apa pun.

\section{DAFTAR PUSTAKA}

Adinugroho, Indro., 2016, “Demokrasi, Kepemimpinan, dan Psikologi Moral”, dalam Buletin Psikologi, V. 24 No. 2, Jakarta.

Aloysius, Widyawan Luis., 2013 "Prinsip Partisipasi dan Solidaritas dalam Visi Personalistik Karol Wojtyla”, dalam Arete, V. 1No. 2, Malang.

Bertens K., 1975, Sejarah Filsafat Yunani: Dari Thales ke Yunani. Yogyakarta: Kanisius.

Departemen Pendidikan Nasional., 2008, Kamus Besar Bahasa Indonesia Pusat Bahasa (edisi keempat). Jakarta: Gramedia Pustaka Utama.

Dister, Nico Syukur., 2004, Teologi Sistematika 1, Allah Penyelamat: Kompendium Sepuluh Cabang Berakar Biblika dan Berbatang Patristika (Teologi Wahyu dan Iman, Teologi Trinitas, Kristologi, Pneumatologi, Teologi Penciptaan, Soteriologi, Eklesiologi, Sakramentologi, Mariologi, Eskatologi. Yogyakarta: Kanisius.

Dewantara, A., W., 2017, “Kerasulan Awam Di Bidang Politik (SosialKemasyarakatan), Dan Relevansinya Bagi Multikulturalisme Indonesia”, dalam JPAK, V. 18 No. 9, Madiun.

Hardiman F., Budi., 2004, Filsafat Modern: Dari Machiavelli Sampai Nietzche. Jakarta: Gramedia Pustaka Utama.

Internasional NGO Forum on Indonesia Development (INFID). Terj. Maria Anik dan Yulia Siswaningsih. Indonesia: Demokratisasi di Era Globalisasi 
(Konferensi INFID Ke-11, Bonn-Jerman, 4-6 Mei 1998). Jakarta: Internasional NGO Forum on Indonesia Development (INFID).

KWI., 2014, Katekismus Gereja Katolik. Flores-NTT: Nusa Indah.

Magnis, Franz., 1995, Kuasa dan Moral. Jakarta: Gramedia. , 2006, Etika Abad Kedua Puluh. Yogyakarta: Kanisius.

Manaek, Sinaga, 2014, “Manusia Sebagai Gambar Allah”, dalam Forum Jurnal Filsafat Teologi, V. 2 No. 2, Surabaya.

Menoh, Gusti A., B., 2015, Agama dalam Ruang Publik: Hubungan Antara Agama dan Negara dalam Masyarakat Postsekuler Menurut Jürgen Habermas. Yogyakarta: Kanisius.

Olla, Paulinus Yan., 2002, Spiritualitas Politik: Kesucian Politik dalam Perspektif Kristiani. Jakarta: Gramedia Pustaka Utama.

Pius, Pandor, "Menyibak Tabir Politik Otentik Arentian: Sebuah Pembacaan dari Perspektif Etika Politik”, dalam Arete Jurnal Filsafat, V. 02, No.01, Malang.

Prabantoro, Putut, "Hidup Katolik, 17/07/2017: https://www.hidupkatolik.com, diunduh 21/05/2019, pukul 23.20 WIB.

Rachels, James., 2004, Filsafat Moral. Yogyakarta: Kanisius.

Riyanto, Armada., 2011, Berfilsafat Politik. Yogyakarta: Kanisius.

Setiawan, dan Sudrajat, 2018, "Pemikiran Postmodernisme dan Pandangannya Terhadap Ilmu Pengetahuan”, dalam JURNAL FILSAFAT, vol. 28. No. 1. Yogyakarta.

Sudiarja, dkk (penyunting)., 2006. Driyarkara. Karya Lengkap Driyarkara: Esaiesai Filsafat Pemikir yang Terlibat dalam Perjuangan Bangsanya. Jakarta: Gramedia Pustaka Utama (hlm. 1035-1141).

Wogaman, Philip., 2000,Christian perspectivesonPolitics(revisedandexpanded). Louisville - Kentucky: Wesminters John Knox Press. 